\title{
Topography Modulates Effects of Nitrogen Deposition on Microbial Resource Limitation in a Nitrogen-Saturated Subtropical Forest
}

Hao Chen

Sun Yat-sen University

Junjie Tang

Chinese Academy of Sciences

Xibin Sun

Sun Yat-Sen University

Kayan Ma

Sun Yat-Sen University

Huaihai Chen

Sun Yat-Sen University

Dejun Li ( $\boldsymbol{D}$ lidejun@hotmail.com )

Chinese Academy of Sciences

\section{Research Article}

Keywords: nitrogen deposition, topography, nutrient limitation, $\mathrm{N}$ saturation, enzyme activity, enzymatic stoichiometry

Posted Date: July 20th, 2021

DOl: https://doi.org/10.21203/rs.3.rs-699904/v1

License: (c) (1) This work is licensed under a Creative Commons Attribution 4.0 International License. Read Full License 


\section{Abstract \\ Background}

Nitrogen $(\mathrm{N})$ saturation theory proposes that an ecosystem might switch from $\mathrm{N}$ limitation to carbon (C), phosphorus $(\mathrm{P})$, or other nutrient limitations if it receives continuous $\mathrm{N}$ input. Yet, after $\mathrm{N}$ limitation is removed, which nutrient is the most limited and whether topography modulates such change is rarely tested at a microbial level. Here, we conducted a two-year $\mathrm{N}$ addition experiment under two different topography positions (i.e. a slope and a valley) in a N-saturated subtropical forest. Soil enzyme activity was measured, and ecoenzymatic stoichiometry indexes were calculated as indicators of microbial resource limitation.

\section{Results}

In the valley, two-year $\mathrm{N}$ addition changed the activity of all studied enzymes to various degrees. As a result, microbial $\mathrm{C}$ limitation was aggravated in the valley, and consequently microbial decomposition of soil labile organic $\mathrm{C}$ increased, but microbial $\mathrm{P}$ limitation was alleviated due to the stoichiometry balance. On the slope, however, $\mathrm{N}$ addition did not significantly change the activity of the studied enzymes, and did not alter the status of microbial resource limitation.

\section{Conclusions}

These results indicate that $\mathrm{C}$ is a more limited element for microbial growth than $\mathrm{P}$ after removing $\mathrm{N}$ limitation, but we also highlight that topography can regulate the effect of $\mathrm{N}$ deposition on soil microbial resource limitation in subtropical forests. These findings provide useful supplements to the $\mathrm{N}$ saturation theory.

\section{Introduction}

Over the past few decades, atmospheric nitrogen $(\mathrm{N})$ deposition increased rapidly, and changed the structure and function of terrestrial ecosystems (Galloway et al. 2008). To describe effects of $\mathrm{N}$ deposition on ecosystems, a $\mathrm{N}$ saturation theory was developed basing on studies from temperate forests (Aber et al. 1989). One view of this theory proposes that continuous $\mathrm{N}$ input may reduce system requirements for $\mathrm{N}$, and finally the system may become $\mathrm{N}$-saturated. In this case, carbon (C), phosphorus (P) or water limitation is expected to occur or be aggravated (Aber et al. 1989). This is a useful theory for predicting dynamics of terrestrial ecosystems in response to increased $\mathrm{N}$ deposition (Chen et al. 2018d).

This proposition, however, has yet to specify which nutrient would be the most limited after removing $\mathrm{N}$ limitation. In plants, this topic has been studied widely. Recent studies tend to suggest that $\mathrm{N}$ deposition mav switch $\mathrm{N}$ limitation to P limitation (Braun et al. 2010; Crowley et al. 2012; Deng et al. 2017; Gress et Loading [MathJax]/jax/output/CommonHTML/jax.js 
al. 2007; Li et al. 2016), although some studies find no effects (Finzi 2009; Weand et al. 2010) or other limitations, such as calcium (Ca) limitation (McNulty et al. 1996). In microbes, however, the discussion is relatively few, and the situation might differ from of plants. For microbes, $\mathrm{C}$ is often a more limited element compared to N, P or other nutrients (Soong et al. 2020). Thus, when N limitation is removed after continuous $\mathrm{N}$ input, $\mathrm{C}$ may be the most limited factor for microbial growth, rather than $\mathrm{P}$ or other nutrients. However, this expectation is not consistent with many recent studies, which suggest that $\mathrm{N}$ addition may aggravate microbial P limitation (Marklein and Houlton 2012). Since microbes are as important as plants in an ecosystem, more studies are undoubtedly needed to address how microbial resource limitation changes after increased $\mathrm{N}$ deposition.

The ecoenzymatic stoichiometry method provides a new tool to study such topic. Compared to traditional methods that measure effects of substrate additions on microbial biomass or respiration as indicators of microbial resource limitation (Traoré et al. 2016), ecoenzymatic stoichiometry has a number of advantages. First, it is much faster, because it measures activities of only four enzymes, including $\beta$-Dglucosidase (BG), L-leucine aminopeptidase (LAP), $\beta$-N-acetylglucosaminidase (NAG), and acid/alkaline phosphatase (AP). Second, using enzymes as proxy indicators of $C, N$, and $P$ acquisition, it is much easier for us to understand which nutrient is more limited to an ecosystem (Sinsabaugh 1994). However, most previous studies reported effects of $\mathrm{N}$ addition on the activity of the single enzyme (Chen et al. 2016; Jian et al. 2016; Marklein and Houlton 2012), very few studies have assessed responses of ecoenzymatic stoichiometry to $\mathrm{N}$ additions (Wang et al. 2015). By collecting published data regarding single enzyme activity in response to $\mathrm{N}$ addition, a previous meta-analysis reported that nitrogen deposition may aggravate microbial C limitation (Chen et al. 2018d). However, this study has limitations: firstly, the selected published studies rarely reported $\mathrm{C}, \mathrm{N}$, and $\mathrm{P}$ acquisition enzymes at the same time, which largely limited the data's comparability and the conclusion's generality; secondly, most selected studies were conducted in $\mathrm{N}$-limited systems rather than $\mathrm{N}$-saturated systems, and thus cannot answer the above question regarding changes of resource limitation after a system has been $\mathrm{N}$-saturated. These limitations highlight the importance of more field experiments conducted in $\mathrm{N}$-saturated systems and more experiments measuring enzymes fully for calculating ecoenzymatic stoichiometry.

Topography can modulate many microbial processes, but is often ignored in the previous N-deposition studies. Most $\mathrm{N}$-deposition simulation experiments were conducted in one topography position (mostly in flat ground) or did not distinguish topography positions (Zhang et al. 2021), while few experiments estimated whether and how topography regulates the responses of microbial processes to $\mathrm{N}$ deposition (Zhang et al. 2013). In a previous study, divergent responses of soil asymbiotic $\mathrm{N}_{2}$ fixation to $\mathrm{N}$ addition has been found between the valley and slope, implying the important effect of topography on ecosystem processes (Wang et al. 2019). However, whether microbial resource limitation status has similar responses needs further exploration. In general, soil $\mathrm{N}$ level will be lower in the upslope (due to erosion) than in the downslope or valley (Weintraub et al. 2015), resulting in a higher sensitivity of microbes to the addition of $\mathrm{N}$ in the upslope than in the downslope or valley. Nevertheless, the $\mathrm{N}$ leaching will be higher in the upslope than in the downslope or valley (Wang et al. 2019), which in turn weakens the $\mathrm{N}$ addition 
effects. These contrary mechanisms make the topography effects uncertain. Lacking knowledge of topography effects has become an important limitation for model prediction regarding responses of terrestrial ecosystem processes to atmospheric $\mathrm{N}$ deposition.

Therefore, in this study we conducted a two-year $\mathrm{N}$ addition experiment in a subtropical karst forest, where soil microbes have been proven to be $\mathrm{N}$-saturated (Chen et al. 2018b), to test how $\mathrm{N}$ deposition changes the status of microbial resource limitation in such a $\mathrm{N}$-saturated situation. In order to investigate whether topography regulates effects of $\mathrm{N}$ additions on microbial resource limitation status, the $\mathrm{N}$ addition experiment was set up at two topography positions, i.e., a valley and a slope. To our knowledge, this is the first $\mathrm{N}$-deposition simulation experiment site that considers the effects of topography in the subtropical forest. We hypothesized that 1 ) nitrogen deposition may aggravate microbial C limitation based on the previous studies; and 2) the response of microbial limitation to nitrogen additions may differ between valley and slope.

\section{Materials And Methods}

\section{Site description}

The studied forest locates in Mulun National Nature Reserve of Huanjiang County, southwest China $\left(24^{\circ} 54^{\prime}-24^{\circ} 07^{\prime} \mathrm{N}, 107^{\circ} 56^{\prime}-108^{\circ} 00^{\prime} \mathrm{E} ; 299-686 \mathrm{~m}\right.$ a.s.l) (Wang et al. 2019). This area has a monsoon climate. Mean annual temperature is about $19^{\circ} \mathrm{C}$, with the lowest monthly mean in January and the highest in July. The mean annual precipitation is about $1389 \mathrm{~mm}$, with a distinct seasonal pattern: the wet season is from April to October and the dry season is from November to March. The selected forest is about 35 years old after clear-cut, dominated by Cryptocar-yachinensis (Hance) Hemsl., Cinnamomum saxatile H. W. Li, Koelreuteria minor Hemsl., Pittosporum tobira (Thunb.) Ait., Bridelia tomentosa Bl., Murraya exotica L. Mant. The soil is leptosols based on the FAO World Reference Base for Soil Resources (IUSS-Working-Group 2006). More detailed information of soil properties can be found in a previous study (Wang et al. 2019) .

\section{Experimental design}

The experiment was initiated in April 2016 (Wang et al. 2019). The experiment was conducted in the valley and on the slope, respectively, where the soil properties are different (Table 1): there are higher concentrations of soil organic $\mathrm{C}$, total $\mathrm{N}_{1} \mathrm{NO}_{3}{ }^{-}$, and $\mathrm{Ca}$ and greater $\mathrm{NO}_{3}{ }^{-}$leaching rate on the slope than in the valley. In each position, a randomized block design was adopted with three $\mathrm{N}$ treatments and three blocks: control (CT, $0 \mathrm{~kg} \mathrm{~N} \mathrm{ha}^{-1} \mathrm{yr}^{-1}$ ), low-N addition ( $\mathrm{LN}, 50 \mathrm{~kg} \mathrm{~N} \mathrm{ha}^{-1} \mathrm{yr}^{-1}$ ) and high-N addition (HN, $\left.100 \mathrm{~kg} \mathrm{~N} \mathrm{ha}^{-1} \mathrm{yr}^{-1}\right)$. Thus, there are 18 plots $(10 \mathrm{~m} \times 10 \mathrm{~m}$ each) in total. Each plot is surrounded by a 10 $\mathrm{m}$ wide buffer strip. $\mathrm{NH}_{4} \mathrm{NO}_{3}$ was weighed and mixed with $10 \mathrm{~L}$ of water (equals to $1.2 \mathrm{~mm}$ annual precipitation) for each $\mathrm{N}$-treatment plot, and the $\mathrm{NH}_{4} \mathrm{NO}_{3}$ solution was sprayed every month to the forest floor with a backpack sprayer. The control plots received $10 \mathrm{~L}$ of water without fertilizer. 
Table 1

The differences in soil properties between slope and valley. $\mathrm{BD}, \mathrm{SOC}, \mathrm{TN}, \mathrm{TP}, \mathrm{NH}_{4}{ }^{+}, \mathrm{NO}_{3}{ }^{-}, \mathrm{Ca}$ and $\mathrm{Mg}$ are bulk density, soil organic carbon, total nitrogen, nitrate, ammonium, calcium and magnesium, respectively. Value is mean (standard error).

Different letters denote the significant difference between treatments.

\begin{tabular}{|lll|}
\hline & Valley & Slope \\
\hline $\mathrm{BD}\left(\mathrm{g} \mathrm{cm}^{-3}\right)$ & $0.90(0.04)$ & $0.95(0.05)$ \\
$\mathrm{pH}$ & $7.19(0.17)$ & $7.32(0.54)$ \\
\hline $\mathrm{SOC}\left(\mathrm{g} \mathrm{kg}^{-1}\right)$ & $40.46(3.77) \mathrm{b}$ & $52.24(5.01) \mathrm{a}$ \\
\hline $\mathrm{TN}\left(\mathrm{g} \mathrm{kg}^{-1}\right)$ & $3.74(0.35) \mathrm{b}$ & $4.72(0.50) \mathrm{a}$ \\
\hline $\mathrm{TP}\left(\mathrm{g} \mathrm{kg}^{-1}\right)$ & $2.26(0.16)$ & $1.91(0.22)$ \\
\hline $\mathrm{NH}_{4}{ }^{+}-\mathrm{N}\left(\mathrm{mg} \mathrm{kg}^{-1}\right)$ & $7.60(0.41)$ & $5.68(0.26)$ \\
\hline $\mathrm{NO}_{3}{ }^{-} \mathrm{N}\left(\mathrm{mg} \mathrm{kg}^{-1}\right)$ & $19.91(3.01) \mathrm{a}$ & $13.33(1.07) \mathrm{b}$ \\
\hline $\mathrm{Ca}^{\left(\mathrm{g} \mathrm{kg}^{-1}\right)}$ & $7.04(0.70) \mathrm{b}$ & $14.80(2.1) \mathrm{a}$ \\
\hline $\mathrm{NO}_{3}{ }^{-}$leaching rate & $3.27(0.01) \mathrm{b}$ & $5.01(0.01) \mathrm{a}$ \\
$\left(\mathrm{mg} \mathrm{d}^{-1} \mathrm{~kg}^{-1} \mathrm{dry}\right.$ resin) & & \\
\hline
\end{tabular}

\section{Soil sampling and lab experiments}

Soil sampling was conducted twice in May, 2017 and 2018, respectively. In each plot, five soil cores were collected and mixed into a composite sample. Soils were passed through a $2 \mathrm{~mm}$ mesh sieve after picking out roots and stones. The sieved soil samples were divided into two portions for further processes. One portion was air-dried at room temperature for analyzing soil properties, including soil organic $C$ (SOC), total N (TN), total P (TP), dissolved organic C (DOC), total dissolved N (TDN), and available P (AVP) (Carter and Gregorich 2006; Lasota and Błońska 2021). Another portion were kept on ice in the field and were stored at $4{ }^{\circ} \mathrm{C}$ in the laboratory for analyses of soil $\mathrm{NH}_{4}{ }^{+}$and $\mathrm{NO}_{3}{ }^{-}$concentrations, microbial biomass $C$ (MBC), $N(M B N)$, and $P(M B P)$, and extracellular enzyme activity (Chen et al. 2018b). Soil $\mathrm{NH}_{4}{ }^{+}$and $\mathrm{NO}_{3}{ }^{-}$concentrations were analyzed by an autoanalyzer (FIAstar 5000, FOSS, Sweden). $\mathrm{MBC}, \mathrm{MBN}$, and MBP were determined by the chloroform fumigation extraction method (Brookes et al. 1985; Brookes et al. 1982; Vance et al. 1987). The nitrification rate and $\mathrm{NO}_{3}{ }^{-}$leaching rate were measured and provided by Liang Zheng in 2018. 
Enzyme activity assays were conducted within two weeks after soil sampling. $\beta$-D-glucosidase (BG), LLeucine aminopeptidase (LAP), $\beta$-N-acetylglucosaminidase (NAG), and acid phosphatase (AP) were assayed with published microplate protocols. In addition, in order to model decomposition rates, we also measured the activity of ligninolytic enzyme (i.e. polyphenol oxidase [POX]) with a spectrophotometrical method. Detailed assay processes can be found in our previous studies (Chen et al. 2018b; Chen et al. 2017). Enzyme activity was expressed to units per $\mathrm{g}$ of soil organic carbon, i.e., $\mu \mathrm{mol} \mathrm{g} \mathrm{g}^{-1} \mathrm{SOC}^{-1}$.

\section{Ecoenzymatic stoichiometry}

Several methods were used to reflect microbial resource limitation status. First, simple ratios of enzyme activities were used. Higher BG/(LAP + NAG) and BG/AP indicate lower $\mathrm{N}$ and P limitation, respectively (Waring et al. 2014). Second, vector length and angle of ecoenzymatic stoichiometry was conducted as follows (Moorhead et al. 2013):

$$
\text { Vector length (unitless) }=\sqrt{(\operatorname{lnBG} / \ln [N A G+L A P])^{2}+(\ln B G / \ln A P)^{2}}(1)
$$

Vector angle $\left({ }^{\circ}\right)=\operatorname{Degrees}(A T A N 2((\ln B G / \ln A P),(\operatorname{lnBG} / \ln [N A G+L A P])))(2)$ vector length indicates greater $\mathrm{C}$ limitation; vector angles of $<45^{\circ}$ and $>45^{\circ}$ indicate $\mathrm{N}$ and $\mathrm{P}$ limitation, respectively (Moorhead et al. 2013).

Third, $C: N$ and $C: P$ of the available resources (DOC/TDN $\left(R_{C: N}\right)$ and DOC/AVP $\left(R_{C: P}\right)$, respectively) were compared to the Threshold Elemental Ratios (TER) for C:N and C:P (TER $\mathrm{C}: \mathrm{N}_{\mathrm{N}}$ and TER $\mathrm{C}: \mathrm{P}$, respectively). When $\mathrm{R}_{\mathrm{C}: \mathrm{N}}-\mathrm{TER}_{\mathrm{C}: \mathrm{N}}$ or $\mathrm{R}_{\mathrm{C}: \mathrm{P}}-\mathrm{TER}_{\mathrm{C}: \mathrm{P}}$ is less than zero, soil microbes are not limited by $\mathrm{N}$ or $\mathrm{P}$. When the $\mathrm{R}_{\mathrm{C}: \mathrm{N}^{-}}-\mathrm{TER}_{\mathrm{C}: \mathrm{N}}$ or $\mathrm{R}_{\mathrm{C}: \mathrm{P}}-\mathrm{TER}_{\mathrm{C}: \mathrm{P}}$ is greater than zero, microbes are $\mathrm{N}$ or $\mathrm{P}$ limited. In the latter case, higher $\mathrm{R}_{\mathrm{C}: \mathrm{N}}-\mathrm{TER}_{\mathrm{C}: \mathrm{N}}$ or $\mathrm{R}_{\mathrm{C}: \mathrm{P}}-\mathrm{TER}_{\mathrm{C}: \mathrm{P}}$ indicate higher $\mathrm{N}$ or P limitation (Sterner and Elser 2002). $\mathrm{TER}_{\mathrm{C}: \mathrm{N}}$ and $\mathrm{TER}_{\mathrm{C}: \mathrm{P}}$ were calculated as follows (Sinsabaugh et al. 2009):

$$
\begin{gathered}
\mathrm{TER}_{\mathrm{C}: \mathrm{N}}=(\mathrm{BG} /(\mathrm{NAG}+\mathrm{LAP})) \times \mathrm{B}_{\mathrm{C}: \mathrm{N}} / \mathrm{n}_{0}(3) \\
\mathrm{TER}_{\mathrm{C}: \mathrm{P}}=(\mathrm{BG} / \mathrm{AP}) \times \mathrm{B}_{\mathrm{C}: \mathrm{P}} / \mathrm{p}_{0}(4)
\end{gathered}
$$

where $\mathrm{B}_{\mathrm{C}: \mathrm{N}}$ and $\mathrm{B}_{\mathrm{C}: \mathrm{P}}$ are $\mathrm{C}: \mathrm{N}$ and $\mathrm{C}: \mathrm{P}$ ratios of microbial biomass, and $n_{0}$ and $p_{0}$ are the intercepts calculated from regressions of $\ln (B G)$ vs $\ln (N A G+L A P)$ and $\ln (B G)$ vs $\ln (A P)$, respectively.

We also modeled organic $C$ decomposition $\left(M, \%\right.$ day $\left.^{-1}\right)$ (Sinsabaugh and Moorhead 1994):

$$
M=\left(C U E \times E N Z_{T O T}\right) /(1+([N A G+L A P] / B G)+(A P / B G))(6)
$$

where $\mathrm{ENZ}_{\mathrm{TOT}}$ is the sum of $\mathrm{BG}, \mathrm{POX},(\mathrm{BG}+\mathrm{LAP})$, and $\mathrm{AP}$ normalized to their maximum values. $\mathrm{CUE}$ is carbon use efficiency, which was calculated according to previous studies (Chen et al. 2018b; Li et al. 2021; Sinsabaugh et al. 2013).

\section{Data analysis}


In this study, soil enzyme activity had no responses to one-year $\mathrm{N}$ addition, but had significant changes after two years of $\mathrm{N}$ addition. Thus, in the following analyses we only focused on the results after two years of $\mathrm{N}$ additions. One-way analysis of variance (ANOVA) with least significant difference (LSD) test was used to test the effects of the two-year $\mathrm{N}$ addition on soil properties, enzyme activities and ecoenzymatic stoichiometry indexes. A one-sample t-test was used to test the difference between $\mathrm{R}_{\mathrm{C}: \mathrm{N}}{ }^{-}$ $\mathrm{TER}_{\mathrm{C}: \mathrm{N}}$ (or $\mathrm{R}_{\mathrm{C}: \mathrm{P}}-\mathrm{TER}_{\mathrm{C}: \mathrm{P}}$ ) and zero, and the difference between vector angle and $45^{\circ}$. All statistical analyses were conducted using SPSS 16.0 statistical software (SPSS Inc., Chicago, IL, USA). All reported significant differences are at $P<0.05$.

\section{Results}

In the control, mean enzyme activities were $1.9 \pm 0.1,31.7 \pm 4,0.01 \pm 0.01,0.6 \pm 0.04$, and $1.8 \pm 0.1 \mu \mathrm{mol}$ $\mathrm{g}^{-1} \mathrm{SOC}^{-1}$ for BG, POX, LAP, NAG, and AP, respectively, and there were no significant difference between slope and valley (Fig. 1). On the slope, $\mathrm{N}$ addition did not change activities of all studied enzymes (Fig. 1). In the valley, $\mathrm{N}$ addition changed activities of all studied enzymes after two years of $\mathrm{N}$ treatments (Fig. 1). The BG and NAG activities increased significantly in the high-N treatment compared to the control (Fig. 1a, d), and AP activity increased significantly in both high-N and low-N addition treatments (Fig. 1e), but POX and LAP activities decreased significantly in the high-N treatment (Fig. 1c, b).

As for ecoenzymatic stoichiometry, $\mathrm{N}$ addition did not change any indexes of ecoenzymatic stoichiometry on the slope position (Figs. 2 and 3). However, in the valley, $\mathrm{N}$ additions significantly increased BG/AP and vector length (Fig. 2a, b), but did not change the $B G /(L A P+N A G)$ in both low and high $N$ treatments compared to the control (Fig. 2c). $\mathrm{R}_{\mathrm{C}: \mathrm{N}^{-}}-\mathrm{TER}_{\mathrm{C}: \mathrm{N}}$ was significantly lower than zero in the control, and $\mathrm{N}$ addition significantly decreased $\mathrm{R}_{\mathrm{C}: \mathrm{N}}-\mathrm{TER}_{\mathrm{C}: \mathrm{N}}$ in both low-N and high-N treatments (Fig. 2d). Vector angle in the control was significantly greater than $45^{\circ}$, and $\mathrm{N}$ addition significantly decreased vector angle in the high- $\mathrm{N}$ treatment (not in the low- $\mathrm{N}$ treatment). $\mathrm{R}_{\mathrm{C}: \mathrm{P}}-\mathrm{TER}_{\mathrm{C}: \mathrm{P}}$ in the control was significantly greater than zero, and both low-N and high $\mathrm{N}$ treatments significantly increased $\mathrm{R}_{\mathrm{C}: \mathrm{P}}-\mathrm{TER}_{\mathrm{C}: \mathrm{P}}(\mathrm{Fig}$. 2e, $\mathrm{f})$. In addition, $\mathrm{N}$ addition significantly increased the modeled decomposition rate (M) in both low- $\mathrm{N}$ and high- $\mathrm{N}$ treatments, and significantly decreased BG/POX in the high-N treatment (Fig. 3a, b).

Two-year $\mathrm{N}$ addition also changed soil properties (Fig. 4). In the valley, $\mathrm{N}$ addition significantly increased the concentrations of DOC and TDN in the high-N treatment (but not for the low-N treatment), and significantly increased nitrification rate and $\mathrm{NO}_{3}{ }^{-}$leaching rate in both low- $\mathrm{N}$ and high-N treatments, but did not changed other soil variables, including the concentrations of SOC, TN, TP, AVP, MBC, MBN, MBP, $\mathrm{NH}_{4}{ }^{+}$and $\mathrm{NO}_{3}{ }^{-}$. On the slope, $\mathrm{N}$ addition significantly increased nitrification rate and $\mathrm{NO}_{3}{ }^{-}$leaching rate in both low-N and high-N treatments, but had no significant effects on other studied variables (Fig. 4 and Table S1).

\section{Discussion}




\section{Responses of microbial enzyme activity to $\mathbf{N}$ additions}

The mean enzyme activities measured in controls are similar to those measured in nearby forests (Chen et al. 2018a; Chen et al. 2018b). Nitrogen addition did not change activities of all studied enzymes after one year of $\mathrm{N}$ treatments in all topography positions (data not shown), but started to alter soil enzyme activity two years later in the valley, especially in high- $\mathrm{N}$ treatments, indicating that the duration and rate of $\mathrm{N}$ addition are important factors affecting soil enzyme activity. After two years of $\mathrm{N}$ addition, the responses of the individual enzyme activity to $\mathrm{N}$ addition are consistent with the patterns reported in the recent meta-analysis studies (Chen et al. 2018c; Jian et al. 2016): in the valley, the BG, NAG, and AP activity increased significantly, but POX and LAP activity decreased significantly with the elevated $\mathrm{N}$ addition (Fig. 1). This is interesting, because it may reflect a general change of enzyme activity in response to $\mathrm{N}$ addition. If so, the results of ecoenzymatic stoichiometry in this study can represent not only a regional pattern, but also for other regions.

\section{Responses of microbial resource limitation to $\mathbf{N}$ additions in the valley}

We confirmed that the studied forest is $\mathrm{N}$-saturated, and found that $\mathrm{N}$ addition makes the symptom of $\mathrm{N}$ saturation more obvious. There are several lines of evidence to indicate that the studied forest is $\mathrm{N}$ saturated: $\mathrm{R}_{\mathrm{C}: \mathrm{N}}-\mathrm{TER}_{\mathrm{C}: \mathrm{N}}$ was less than zero in controls (in both valley and slope), indicating that the forest is not limited by $\mathrm{N}$ (Fig. 2d); by contrast, this forest may be P-limited because vector angle was greater than $45^{\circ}$ and the $R_{C: P}-T_{C E}$ P was greater than zero in controls (Fig. $2 e$ and $f$ ). These evidence are also found in the previous studies (Chen et al. 2018b). Since this forest has been N-saturated, it is not surprising that continued $\mathrm{N}$ addition make the symptom more obvious, which is evident from that $\mathrm{R}_{\mathrm{C}: \mathrm{N}^{-}}$ TER $_{\mathrm{C}: \mathrm{N}}$ was significantly lower in $\mathrm{N}$ treatments than in the control (Fig. $2 \mathrm{~d}$ ). In addition, increased nitrification rate and $\mathrm{NO}_{3}{ }^{-}$leaching rate (Table 1 ) also support the aggravated $\mathrm{N}$-saturation according to $\mathrm{N}$ saturation theory (Aber et al. 1989) .

We found that $\mathrm{N}$ aggravates microbial $\mathrm{C}$ limitation in this forest, which is consistent with the first hypothesis. The evidence is from the increased vector length in $\mathrm{N}$-addition plots compared to the control (Fig. 2a). Similarly, we also found increased vector length in a previous meta-analysis by collecting enzyme activity data from 36 published $\mathrm{N}$-addition studies (Chen et al. 2018d). Aggravated microbial C limitation has been suggested in many previous $\mathrm{N}$-addition experiments (Treseder 2008). Here, we proposed two likely reasons for the aggravated microbial $\mathrm{C}$ limitation after $\mathrm{N}$ addition in this study. First, it is a result of nutrient balance. To reach a balance of $\mathrm{C}$ and $\mathrm{N}$, microbes will increase decomposition of organic matter to get more available $\mathrm{C}$ as $\mathrm{N}$ increases. This is supported by modeled decomposition rates (M) in this study, which was increased by $43 \%$ and $54 \%$ in low-N and high-N addition, respectively, compared to the control (Fig. 3a). As a result, increase in soil DOC concentration was also found (Table 1). However, in this study, the increased total decomposition rate is mainly attributed to the increased decomposition of the labile $\mathrm{C}$ fraction, rather than the non-labile $\mathrm{C}$ fraction. This can be Loading [MathJax]/jax/output/CommonHTML/jax.js ssed POX (as a result, the decreased BG/POX, Fig. 3b), since 
BG and POX are two different kinds of enzymes to decompose labile C (such as cellulose) and non-labile C fraction (such as lignin), respectively (Chen et al. 2018c). Therefore, the reduced decomposition of nonlabile $\mathrm{C}$ fraction may be another reason for the aggravated microbial $\mathrm{C}$ limitation in this study, because it decreases the sources of available $\mathrm{C}$.

Compared to the aggravated $\mathrm{C}$ limitation, however, $\mathrm{N}$ addition may alleviate microbial $\mathrm{P}$ limitation, because vector angle decreased but $R_{C: P}-T_{C: P}$ increased in N-treatments relative to controls (Fig. 2). This result rejects our general belief that $\mathrm{N}$ addition will lead to $\mathrm{P}$ limitation (Marklein and Houlton 2012). We note that increased AP may be a reason for the alleviated P limitation (Fig. 1e). However, this might be a paradox, because increased AP not only reflects the increased organic $\mathrm{P}$ decomposition (meaning alleviated $\mathrm{P}$ limitation), but also reflects the increased $\mathrm{P}$ demand of microbes (meaning aggravated $\mathrm{P}$ limitation). Instead, we propose that alleviated $\mathrm{P}$ limitation can be explained more directly by the increased BG/AP (Fig. 2b), which indicates that microbes need more C than P. According to Liebig's law of the minimum, the single scarcest resource in relation to plant demands is the most limiting; this means that only one nutrient can limit plant productivity at a time (Liebig 1842). Since $C$ is more limiting relative to $P$ given the result of $B G / A P, N$ addition aggravated $C$ limitation, rather than $P$ limitation.

\section{Topography modulates effects of $\mathrm{N}$ additions}

The aggravated $\mathrm{C}$ limitation or alleviated $\mathrm{P}$ limitation, however, were not found on the slope after two years of $\mathrm{N}$ addition, indicating that topography plays a role in modulating the effects of $\mathrm{N}$ addition on microbial resource limitation. This result supports the second hypothesis. Most previous studies did not consider topography effects when they study the responses of ecosystem processes to atmospheric $\mathrm{N}$ deposition. This bias may over- or under-estimate effects of $\mathrm{N}$ deposition given that most nature ecosystems are not completely flat. In a previous study with the same experimental site, we have found the divergent responses of soil asymbiotic $\mathrm{N}_{2}$ fixation to $\mathrm{N}$ additions between the valley and slope (Wang et al. 2019). Here, we also found similar pattern for microbial activity, further highlighting the importance of topography in regulating the effects of $\mathrm{N}$ deposition on ecosystem processes.

As mentioned before, there might be two contrary mechanisms (i.e., different soil $\mathrm{N}$ levels and $\mathrm{N}$ leaching potentials) controlling the effects of the topography. In the current study, a reason for the weaker impacts of $\mathrm{N}$ addition on the slope may be due to the higher $\mathrm{NO}_{3}{ }^{-}$leaching in this topography position (Table 1). Soil gross nitrification rate in the limestone soil of the karst forest is very fast (Li et al. 2017), so that deposited $\mathrm{NH}_{4}{ }^{+}$would be rapidly transformed to $\mathrm{NO}_{3}{ }^{-}$upon entering the soil. Considering that soil $\mathrm{NO}_{3}{ }^{-}$ is more susceptible to leaching than $\mathrm{NH}_{4}{ }^{+}$, and that more rock outcrops and the greater inclination on the slope, more $\mathrm{NO}_{3}{ }^{-}$would be leached from the slope, which weakens effects of $\mathrm{N}$ addition on microbial activity on the slope.

It is surprising that soil $\mathrm{N}$ level is higher on the slope than in the valley in our studied forest (Table 1), which might be another mechanism making the valley position more sensitive to $\mathrm{N}$ addition relative to the fonn Tham in nuidanon that $\mathrm{N}$ a dditionn ahgnge ecosystem processes, such as soil $\mathrm{C}$ and $\mathrm{N}$ availability,
Loading [MathJax]/jax/output/CommonHTML/jax.js 
more pronouncedly in $\mathrm{N}$ limited than in $\mathrm{N}$ rich ecosystems (Aber et al. 1998; Chen et al. 2015). Higher soil $\mathrm{N}$ status on the slope is not common in nature, but has been found in the karst region of south China (Liu et al. 2011). The divergent Ca contents between valley and slope might be responsible to this phenomenon. In karst forests, soil on the slope generally had a higher Ca content due to the higher rock explosion (Table 1). Because Ca has a protection effect in storing soil organic matter (SOM) (Wen et al. 2017; Wen et al. 2016), soil on the slope has a higher SOM content and thus higher soil $\mathrm{N}$ content relative to the valley.

\section{Conclusions}

The current study made two important discoveries that worth highlighting. First, our findings in the valley position provide an important supplement to the $\mathrm{N}$ saturation theory, which proposes that continued $\mathrm{N}$ addition to an ecosystem will switch $\mathrm{N}$ limitation to other limitations. In plants, most studies suggested that after $\mathrm{N}$ limitation is removed, $\mathrm{P}$ will be the most important element in limiting plant growth. However, this topic is rarely discussed at a microbial level. Carbon and $\mathrm{P}$ are two likely elements to limit microbial growth, and here we suggest that $\mathrm{C}$ will be the more limited element after $\mathrm{N}$ limitation is removed, which is different from the situation in plants. This finding has important implications for the global $\mathrm{C}$ cycling. It explains why $\mathrm{N}$ addition stimulates the early stages of litter decomposition but in general does not affect longer term decomposition rates (Knorr et al. 2005): during the early decomposition phase, excess labile $\mathrm{C}$ availability leads to $\mathrm{N}$ limitation, but in later stage, decomposers become $\mathrm{C}$-limited as $\mathrm{C}: \mathrm{N}$ of decomposing material decreases (Soong et al. 2020). Second, we also found that topography can modulate the effects of $\mathrm{N}$ addition on microbial resource limitation. Considering that most previous studies ignored the topography effects and thus over- or under-estimate $\mathrm{N}$ deposition effects, this study highlight that topography should be included in Earth system models in order to better predict the responses of ecosystem processes to atmospheric $\mathrm{N}$ deposition.

\section{Declarations}

\section{Ethics approval and consent to participate}

Not applicable.

\section{Consent for publication}

Not applicable.

\section{Availability of data and material}

The datasets used in the current study are available from the corresponding author on reasonable request.

\section{Competing interests}


The authors declare that they have no competing interests

\section{Funding}

This work was funded by the National Natural Science Foundation of China (31872691, 41877094, and 31760153), Guangxi Bagui Scholarship Program to Dejun Li, and National High-Level Talents Special Support Program to Dejun Li.

\section{Authors' contributions}

Conceived and design the experiment: Hao Chen, Dejun Li. Obtained data and samples in the field: Junjie Tang. Processed samples in the lab: Junjie Tang, Xibin Sun. Analyzed the data and wrote the manuscript: Hao Chen. All authors read and approved the final manuscript.

\section{Acknowledgements}

We would like to thank Dr. Hu Du and Dr. Zhenchuan Wang for the assistance in fieldwork.

\section{References}

1. Aber J, McDowell W, Nadelhoffer K, Magill A, Berntson G, Kamakea M, McNulty S, Currie W, Rustad L, Fernandez I (1998) Nitrogen saturation in temperate forest ecosystems- Hypotheses revisited. Bioscience 48:921-934

2. Aber JD, Nadelhoffer KJ, Steudler P, Melillo JM (1989) Nitrogen saturation in northern forest ecosystems. Bioscience 39:378-386

3. Braun S, Thomas VF, Quiring R, Fluckiger W (2010) Does nitrogen deposition increase forest production? The role of phosphorus. Environ Pollut 158:2043-2052

4. Brookes PC, Landman A, Pruden G, Jenkinson DS (1985) Chloroform fumigation and the release of soil-nitrogen - a rapid direct extraction method to measure microbial biomass nitrogen in soil. Soil Biol Biochem 17:837-842

5. Brookes PC, Powlson DS, Jenkinson DS (1982) Measurement of microbial biomass phosphorus in soil. Soil Biol Biochem 14:319-329

6. Carter MR, Gregorich EG (2006) Soil sampling and methods of analysis (second edition). Taylor \& Francis Group, Boca Raton, FL, USA

7. Chen H, Li D, Gurmesa GA, Yu G, Li L, Zhang W, Fang H, Mo J (2015) Effects of nitrogen deposition on carbon cycle in terrestrial ecosystems of China: A meta-analysis. Environ Pollut 206:352-360

8. Chen H, Li D, Mao Q, Xiao K, Wang K (2018a) Resource limitation of soil microbes in karst ecosystems. Science of The Total Environment 650:241-248

9. Chen H, Li D, Xiao K, Wang K (2018b) Soil microbial processes and resource limitation in karst and non-karst forests. Funct Ecol 329:61-64 
10. Chen H, Li D, Zhao J, Xiao K, Wang K (2018c) Effects of nitrogen addition on activities of soil nitrogen acquisition enzymes: A meta-analysis. Agr Ecosyst Environ 252:126-131

11. Chen H, Li D, Zhao J, Zhang W, Xiao K, Wang K (2018d) Nitrogen addition aggravates microbial carbon limitation: Evidence from ecoenzymatic stoichiometry. Geoderma 329:61-64

12. Chen H, Luo P, Wen L, Yang L, Wang K, Li D (2017) Determinants of soil extracellular enzyme activity in a karst region, southwest China. European Journal of Soil Biology 80:69-76

13. Chen J, Luo YQ, Li JW, Zhou XH, Cao JJ, Wang RW, Wang YQ, Shelton S, Jin Z, Walker LM, Feng ZZ, Niu SS, Feng WT, Jian SY, Zhou LY (2016) Co-stimulation of soil glycosidase activity and soil respiration by nitrogen addition. Glob Change Biol 23:1328-1337

14. Crowley K, McNeil B, Lovett G, Canham C, Driscoll C, Rustad L, Denny E, Hallett R, Arthur M, Boggs J (2012) Do nutrient limitation patterns shift from nitrogen toward phosphorus with increasing nitrogen deposition across the northeastern United States? Ecosystems 15:940-957

15. Deng Q, Hui D, Dennis S, Reddy KC (2017) Responses of terrestrial ecosystem phosphorus cycling to nitrogen addition: A meta-analysis. Glob Ecol Biogeogr 26:713-728

16. Finzi AC (2009) Decades of atmospheric deposition have not resulted in widespread phosphorus limitation or saturation of tree demand for nitrogen in southern New England. Biogeochemistry 92:217-229

17. Galloway JN, Townsend AR, Erisman JW, Bekunda M, Cai ZC, Freney JR, Martinelli LA, Seitzinger SP, Sutton MA (2008) Transformation of the nitrogen cycle: Recent trends, questions, and potential solutions. Science 320:889-892

18. Gress SE, Nichols TD, Northcraft CC, Peterjohn WT (2007) Nutrient limitation in soils exhibiting differing nitrogen availabilities: what lies beyond nitrogen saturation? Ecology 88:119-130

19. IUSS-Working-Group (2006) World reference base for soil resources 2006. FAO, Rome

20. Jian S, Li J, Chen J, Wang G, Mayes MA, Dzantor KE, Hui D, Luo Y (2016) Soil extracellular enzyme activities, soil carbon and nitrogen storage under nitrogen fertilization: A meta-analysis. Soil Biol Biochem 101:32-43

21. Knorr M, Frey SD, Curtis PS (2005) Nitrogen additions and litter decomposition: A meta-analysis. Ecology 86:3252-3257

22. Lasota J, Błońska E (2021) C:N:P stoichiometry as an indicator of Histosol drainage in lowland and mountain forest ecosystems. Forest Ecosystems 8:39

23. Li D, Yang Y, Chen H, Xiao K, Song T, Wang K (2017) Soil Gross Nitrogen Transformations in Typical Karst and Nonkarst Forests, Southwest China. Journal of Geophysical Research Biogeosciences 122:2831-2840

24. Li T, Wang R, Cai J, Meng Y, Wang Z, Feng X, Liu H, Turco RF, Jiang Y (2021) Enhanced carbon acquisition and use efficiency alleviate microbial carbon relative to nitrogen limitation under soil acidification. Ecological Processes 10:32. doi:10.1186/s13717-021-00309-1 
25. Li Y, Niu S, Yu G (2016) Aggravated phosphorus limitation on biomass production under increasing nitrogen loading: a meta-analysis. Glob Change Biol 22:934-943

26. Liebig J (1842) Animal chemistry, or organic chemistry in its application to physiology and pathologie. Johnson Reprint Corporation, New York

27. Liu S, Zhang W, Wang K, Chen H, Shu S, Tan W (2011) Spatiotemporal heterogeneity of topsoil nutrients in Karst Peak-Cluster depression area of Northwest Guangxi,China. Acta Ecol Sin 31:30363043 (in Chinese)

28. Marklein AR, Houlton BZ (2012) Nitrogen inputs accelerate phosphorus cycling rates across a wide variety of terrestrial ecosystems. New Phytol 193:696-704

29. McNulty SG, Aber JD, Newman SD (1996) Nitrogen saturation in a high elevation New England spruce-fir stand. For Ecol Manage 84:109-121

30. Moorhead DL, Rinkes ZL, Sinsabaugh RL, Weintraub MN (2013) Dynamic relationships between microbial biomass, respiration, inorganic nutrients and enzyme activities: informing enzyme-based decomposition models. Front Microbiol 4:223

31. Sinsabaugh RL, Hill BH, Shah JJF (2009) Ecoenzymatic stoichiometry of microbial organic nutrient acquisition in soil and sediment. Nature 462:795-798

32. Sinsabaugh RL, Manzoni S, Moorhead DL, Richter A (2013) Carbon use efficiency of microbial communities: stoichiometry, methodology and modelling. Ecol Lett 16:930-939

33. Sinsabaugh RL, Moorhead DL (1994) Resource allocation to extracellular enzyme production: A model for nitrogen and phosphorus control of litter decomposition. Soil Biol Biochem 26:1305-1311

34. Sinsabaugh RS (1994) Enzymic analysis of microbial pattern and process. Biol Fertil Soils 17:69-74

35. Soong JL, Fuchslueger L, Maraon-Jimenez S, Torn MS, Janssens IA, Penuelas J, Richter A (2020) Microbial carbon limitation: The need for integrating microorganisms into our understanding of ecosystem carbon cycling. Glob Change Biol 26:1952-1961

36. Sterner RW, Elser JJ (2002) Ecological stoichiometry: the biology of elements from molecules to the biosphere. Princeton University Press, Princeton

37. Traoré O, Kiba DI, Arnold M, Fliessbach A, Oberholzer HR, Nacro HB, Lompo F, Oberson A, Frossard E, Bünemann EK (2016) Fertilization practices alter microbial nutrient limitations after alleviation of carbon limitation in a Ferric Acrisol. Biol Fertil Soils 52:177-189

38. Treseder KK (2008) Nitrogen additions and microbial biomass: A meta-analysis of ecosystem studies. Ecol Lett 11:1111-1120

39. Vance ED, Brookes PC, Jenkinson DS (1987) An extraction method for measuring soil microbial biomass-C. Soil Biol Biochem 19:703-707

40. Wang R, Dorodnikov M, Yang S, Zhang Y, Filley TR, Turco RF, Zhang Y, Xu Z, Li H, Jiang Y (2015) Responses of enzymatic activities within soil aggregates to 9-year nitrogen and water addition in a semi-arid grassland. Soil Biol Biochem 81:159-167 
41. Wang Z, Li D, Zheng M, Chen H, Sun X, Wang K (2019) Topography modulates effects of nitrogen deposition on asymbiotic $\mathrm{N}_{2}$ fixation in soil but not litter or moss in a secondary karst forest. Journal of Geophysical Research: Biogeosciences 124:3015-3023

42. Waring BG, Weintraub SR, Sinsabaugh RL (2014) Ecoenzymatic stoichiometry of microbial nutrient acquisition in tropical soils. Biogeochemistry 117:101-113

43. Weand MP, Arthur MA, Lovett GM, Sikora F, Weathers KC (2010) The phosphorus status of northern hardwoods differs by species but is unaffected by nitrogen fertilization. Biogeochemistry 97:159181

44. Weintraub SR, Taylor PG, Porder S, Cleveland CC, Asner GP, Townsend AR (2015) Topographic controls on soil nitrogen availability in a lowland tropical forest. Ecology 96:1561-1574

45. Wen L, Li D, Chen H, Wang K (2017) Dynamics of soil organic carbon in density fractions during postagricultural succession over two lithology types, southwest China. J Environ Manage 201:199-206

46. Wen L, Li D, Yang L, Luo P, Chen H, Xiao K, Song T, Zhang W, He X, Chen H (2016) Rapid recuperation of soil nitrogen following agricultural abandonment in a karst area, southwest China. Biogeochemistry 129:341-354

47. Zhang J, Li Y, Wang J, Chen W, Tian D, Niu S (2021) Different responses of soil respiration and its components to nitrogen and phosphorus addition in a subtropical secondary forest. Forest Ecosystems 8:37

48. Zhang N, Xu W, Yu X, Lin D, Wan S, Ma K (2013) Impact of topography, annual burning, and nitrogen addition on soil microbial communities in a semiarid grassland. Soil Sci Soc Am J 77:1214-1224

\section{Figures}



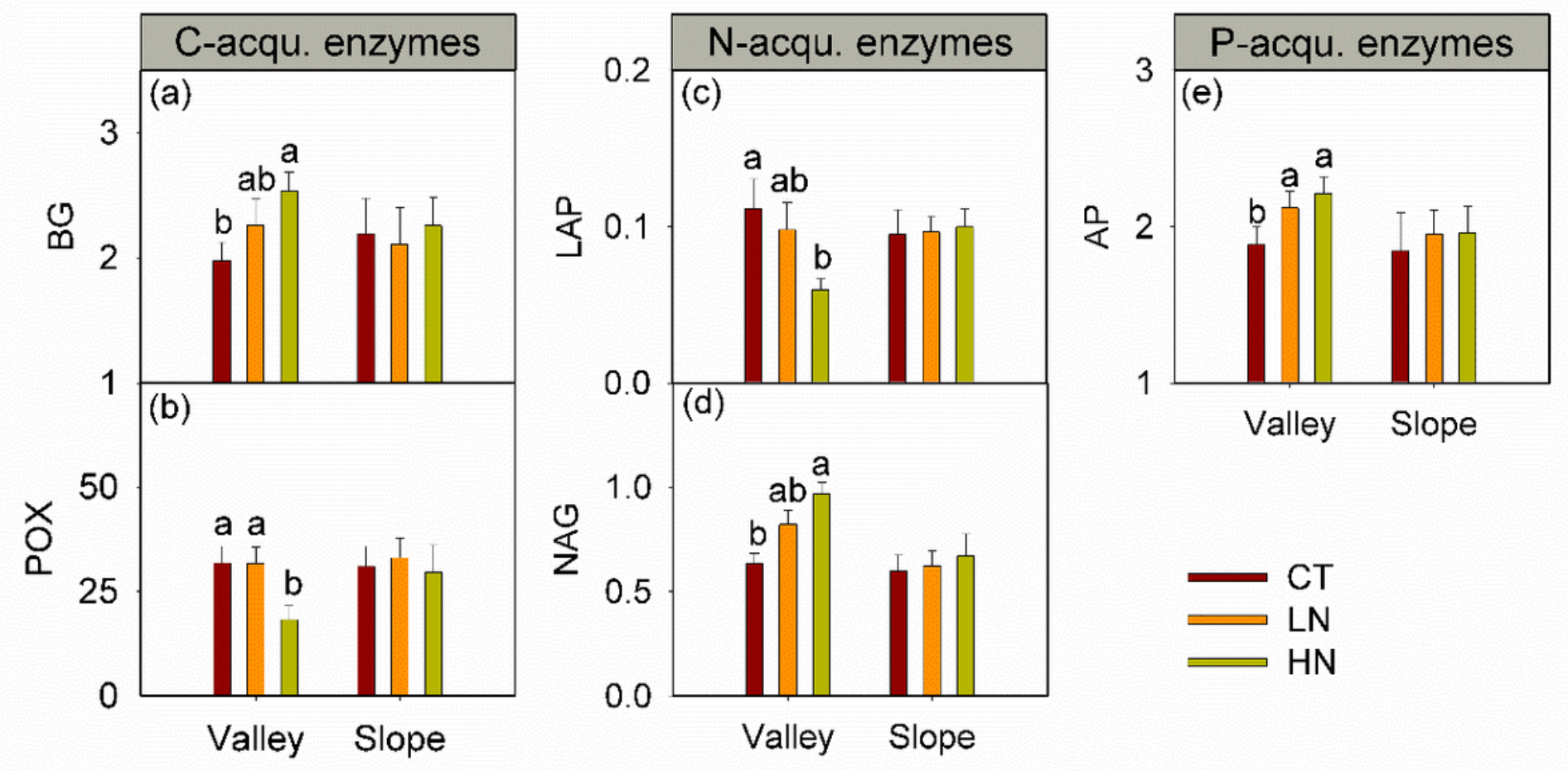

Figure 1

Changes of activities of studied enzymes ( $\mu \mathrm{mol} \mathrm{g-1} \mathrm{SOC} \mathrm{h}-1$ ) after two years of $N$ addition. (a) BG ( $\beta$-Dglucosidase) and (b) POX (polyphenol oxidase) are two C-acqusition enzymes; (c) LAP (L-leucine aminopeptidase) and (d) NAG ( $\beta$-N-acetylglucosaminidase) are two N-acquisition enzymes; (e) AP is a Pacqusition enzyme. CT: control; LN: low-N addition; HN: high-N addition. Error bars denote the standard error $(n=3)$. Different letters indicate significant difference $(P<0.05)$ between treatments. 

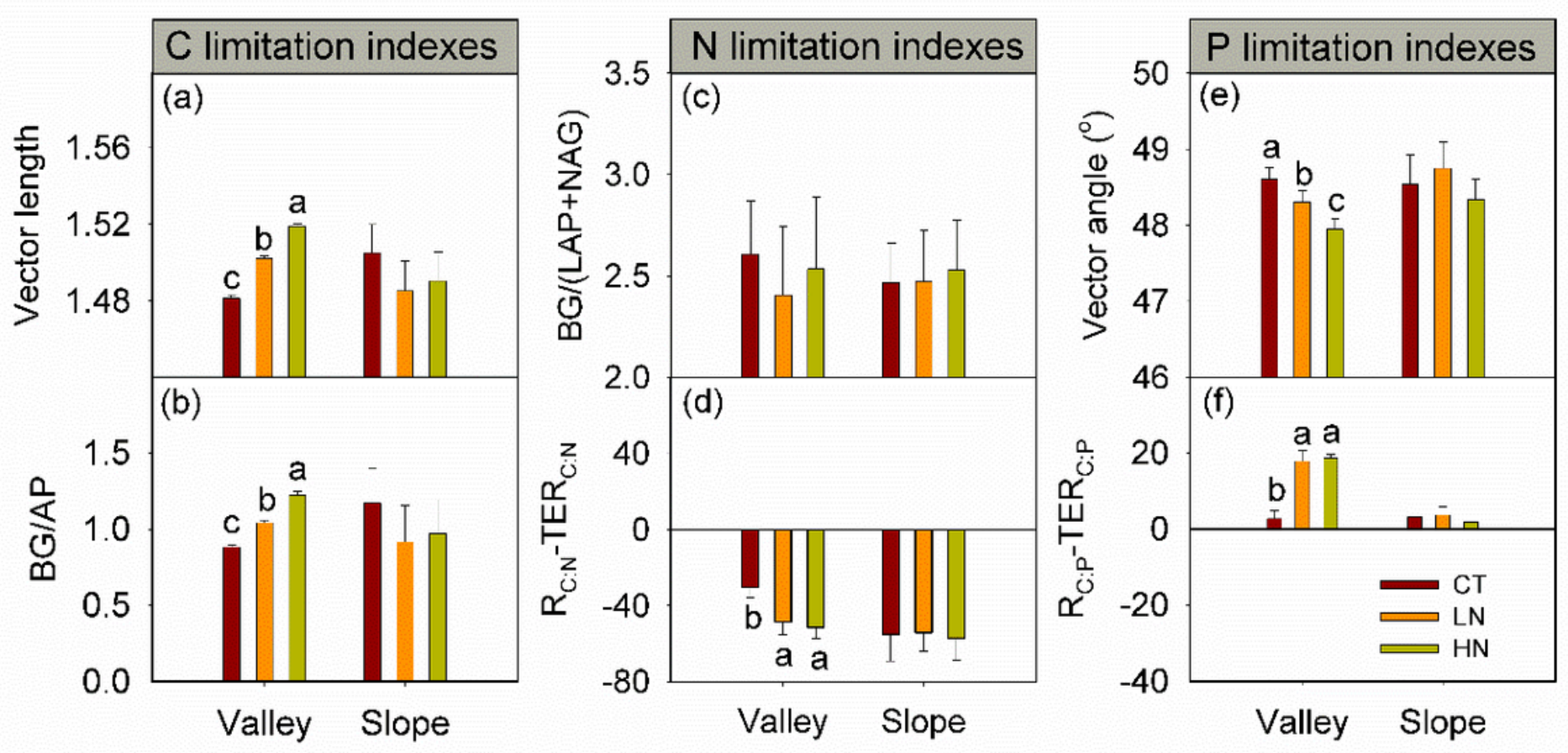

Figure 2

Changes of enzymatic stoichiometry indexes after two years of $\mathrm{N}$ addition. (a) Vector length and (b) $\mathrm{BG} / \mathrm{AP}$ are two indicators of microbial $\mathrm{C}$ limitation. High vector length or BG/AP means greater C limitation. (c) BG/(LAP+ NAG) and (d) RC:N - TERC:N are two indicators of microbial N limiation. High $\mathrm{BG} /(\mathrm{LAP}+\mathrm{NAG})$ means lower $\mathrm{N}$ limitation, while higher RC:N - TERC: $\mathrm{N}$ means higher $\mathrm{N}$ limitation. (e) Vactor angle and (f) RC:P - TERC:P are two indictors of microbial P limitation. Greater vector angle indicates greater $\mathrm{P}$ limitation when vector angles $>45^{\circ}$; higher RC:P - TERC:P means higher $\mathrm{P}$ limitation. CT: control; LN: low-N addition; HN: high-N addition. Error bars denote the standard error $(n=3)$. Different letters indicate significant difference $(P<0.05)$ between treatments. The asterisks indicate significant different between RC:N - TERC:N (or RC:P - TERC:P) and zero. 


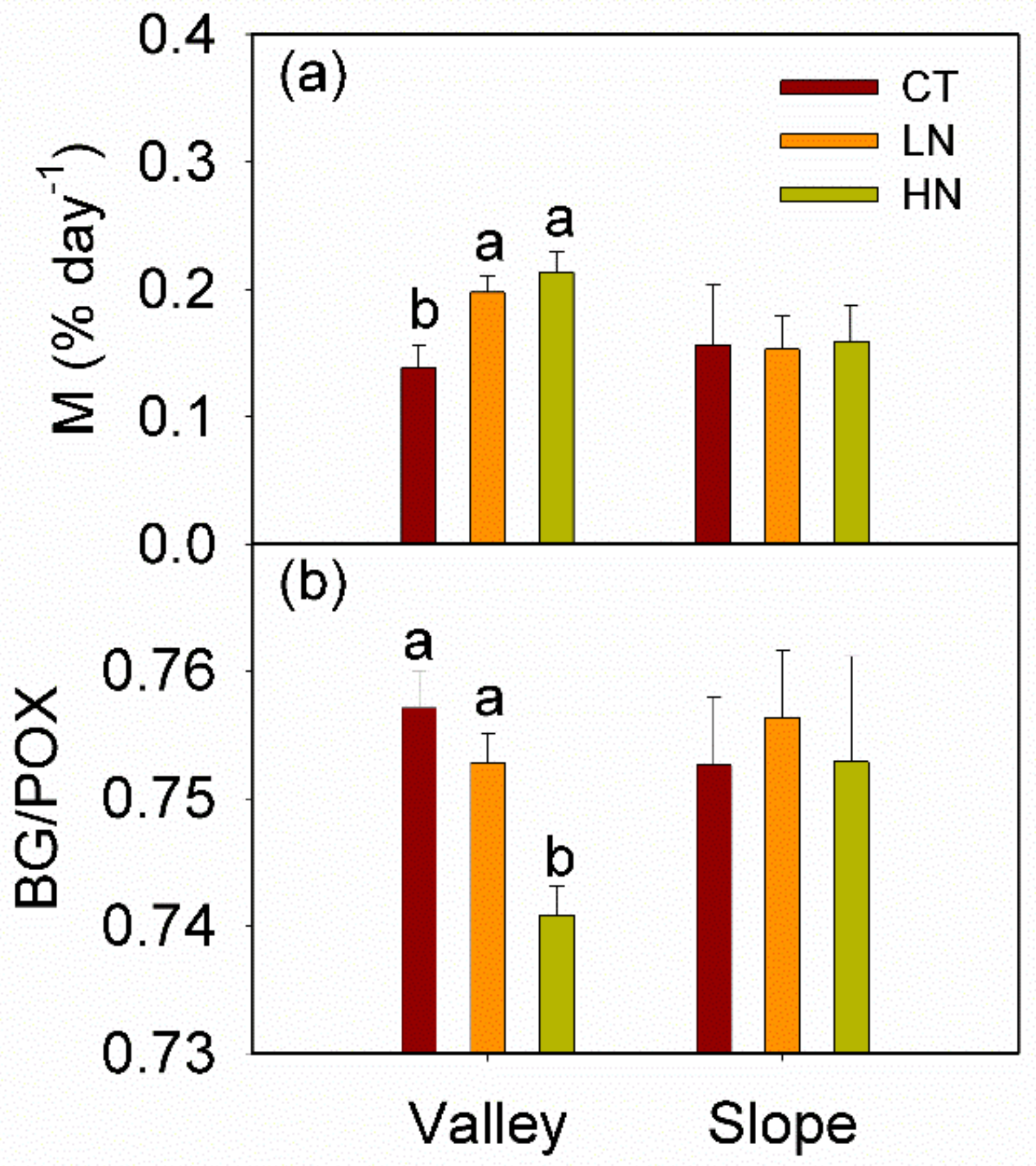

Figure 3

Effects of $\mathrm{N}$ additon on (a) modeled decomposition rate (M) and (b) the ratio of BG (B-D-glucosidase) to POX (polyphenol oxidase). BG and PPO are two C-acqusition enzymes, decomposing labile and non-labile organic $\mathrm{C}$, respectively. $\mathrm{CT}$ : control; $\mathrm{LN}$ : low-N addition; HN: high-N addition. Error bars denote the standard error $(n=3)$. Different letters indicate significant difference $(P<0.05)$ between treatments. 


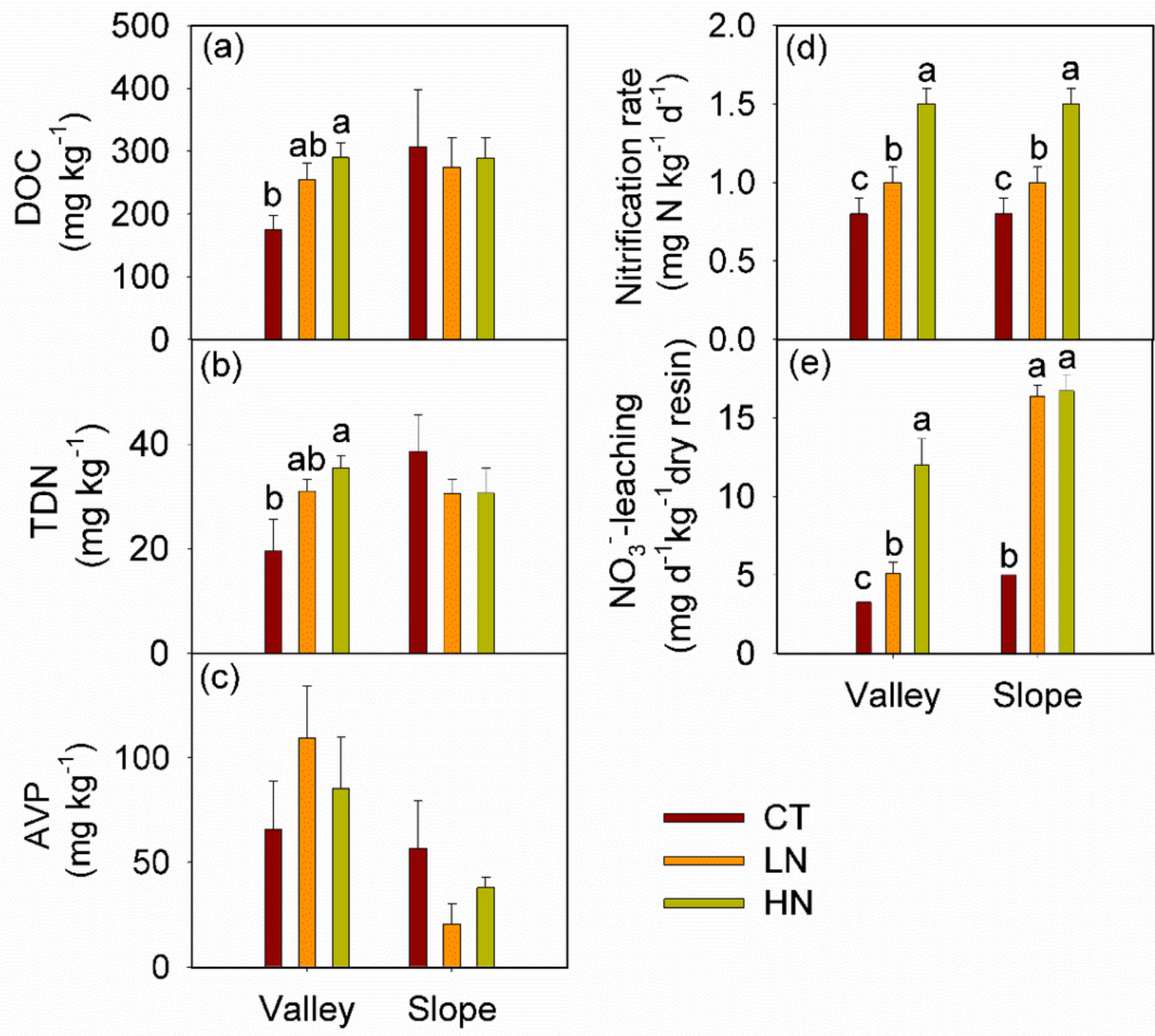

Figure 4

Effects of two-year $\mathrm{N}$ addition on the disoveled organic carbon (DOC), total disoveled nitrogen (TDN), available phosphorus (AVP), nitrification rate, and leaching rate of nitrate (NO3-). The nitrification rate and NO3- leaching rate was provided by Liang Zheng, who measured them in 2018. Error bars denote the standard error $(n=3)$. Different letters indicate significant difference $(P<0.05)$ between treatments.

\section{Supplementary Files}

This is a list of supplementary files associated with this preprint. Click to download. 